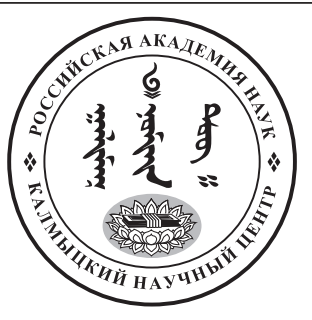

Published in the Russian Federation

Oriental Studies (Previous Name: Bulletin of the Kalmyk Institute

for Humanities of the Russian Academy of Sciences)

Has been issued as a journal since 2008

ISSN: 2619-0990; E-ISSN: 2619-1008

Vol. 13 , Is. 3 , pp. $572-590,2020$

DOI: $10.22162 / 2619-0990-2020-49-3-572-590$

Journal homepage: https://kigiran.elpub.ru

УДК 902 / 903.2

DOI: $10.22162 / 2619-0990-2020-49-3-572-590$

\title{
Элистинский курганный могильник: анализ соотношения курганов и погребений раннего и среднего бронзового века
}

\author{
Эрдни Анатольевич Кекеев ${ }^{l}$
}

${ }^{1}$ Калмыцкий научный центр РАН (д. 8, ул. И. К. Илишкина, 358000 Элиста, Российская Федерация) научный сотрудник

iD 0000-0002-2460-8518. E-mail: kekeev.kekeev@yandex.ru

\author{
(c) КалмНЦ РАН, 2020 \\ (C) Кекеев Э. А., 2020
}

Аннотация. Введение. Элистинский могильник является одним из самых крупных из изученных на территории Ергенинской возвышенности, где основное количество курганов и погребений датировано бронзовым веком. Характерной чертой курганных могильников Ергенинской возвышенности является линейное расположение насыпей - наиболее крупные группы представляют собой цепи курганов, расположенные на линии водоразделов, протянувшихся в широтном направлении. На платообразных гребнях встречаются группы, состоящие из нескольких параллельных цепей курганов. Целью данного исследования является анализ соотношения курганов и погребений культур раннего и среднего бронзового века среди памятников Элистинского могильника. Результатыl. Выявлены особенности использования подкурганного пространства у разных культур изучаемого периода. Курганы ямной культуры содержали только по одному основному погребению. В раннекатакомбный период впускные погребения создавались только в «своих» курганах. С появлением памятников степной северокавказской культуры появились случаи впускных погребений в инокультурных курганах. Ямно-катакомбные погребения носили несколько иной характер использования инокультурных курганов. При устройстве одного из погребений этой группы было разрушено основное погребение в кургане ямного времени. Во втором случае после создания впускного погребения курган был подвергнут значительной досыпке, за счет чего размеры насыпи были увеличены в разы. Характерным для всех памятников является их расположение на линии водораздела без видимых скоплений отдельных насыпей. Наиболее крупная группа памятников - курганы и погребения восточноманычской катакомбной культуры. Катакомбные курганы встраивались в образовавшуюся цепочку, и основная их часть своими размерами практически не отличалась от существующих памятников. Выводыl. В результате проведенного анализа видно, 
что при изучении погребальных памятников раннего и среднего бронзового века важно обращать внимание не только на количественные показатели погребений в отдельных курганах. При подсчете количества впускных погребений обязательно необходимо учитывать культурно-хронологическую принадлежность основного погребения. Кроме того, важно знать такие дополнительные данные, как местоположение погребения в насыпи или под ней, имелись ли следы досыпок и так далее. Эти данные позволяют выявить дополнительные группы впускных погребений, от «рядовых» погребений в насыпи до «престижных» захоронений, после создания которых насыпь значительно увеличивали и порой объем таких досыпок в несколько раз превосходил объем изначальной насыпи.

Ключевые слова: основное погребение, впускное погребение, досыпка, волго-манычские степи, Ергенинская возвышенность, бронзовый век, ямная культура, ранняя катакомбная культура, степная северокавказская культура, ямно-катакомбная группа, восточноманычская катакомбная культура

Благодарность. Исследование проведено в рамках государственной субсидии - проект «Комплексное исследование процессов общественно-политического и культурного развития народов Юга России» (номер госрегистрации: АААА-А19-119011490038-5).

Для цитирования: Кекеев Э. А. Элистинский курганный могильник: анализ соотношения курганов и погребений раннего и среднего бронзового века // Oriental Studies. 2020. Т. 13. № 3. C. 572-590. DOI: 10.22162/2619-0990-2020-49-3-572-590

UDC 902 / 903.2

DOI: 10.22162/2619-0990-2020-49-3-572-590

\title{
Elista Burial Mound Site: Analyzing the Correlation between Early and Middle Bronze Age Mounds and Burials
}

\author{
Erdni A. Kekeev ${ }^{1}$
}

${ }^{1}$ Kalmyk Scientific Center of the RAS (8, Ilishkin St., Elista 358000, Russian Federation)

Research Associate

iD 0000-0002-2460-8518. E-mail: kekeev.kekeev@yandex.ru

\author{
(C) KalmSC RAS, 2020 \\ (C) Kekeev E. A., 2020
}

\begin{abstract}
Introduction. Elista grave field is a largest and most investigated one in the Ergeni Uplands, with the bulk of barrows and burials dated to the Bronze Age. Burial mound sites in the mentioned area are distinguished by linear positioning of tumuli — the most sizeable groups constitute chains of kurgans located transversally along watershed lines. Plateau-like ridges may comprise groups consisting of several parallel kurgan chains. Goals. The study aims at analyzing the correlation (ratio) between kurgans and burials of Early and Middle Bronze Age cultures within the grave field of Elista. Results. The work reveals some specific functions of under-kurgan rooms (space) in different cultures of the examined period. So, burial mounds of the Yamnaya culture contained one central burial each. In the Early Catacomb era, inlet burials were made only in 'own' barrows, while the arrived North Caucasian steppe culture gave rise to scattered cases of constructing inlet burials in culturally alien kurgans. Pit-catacomb burials were characterized by somewhat differing use of foreign culture barrows: one such construct virtually demolished the main burial in a Yamnaya kurgan; in another instance, the creation of an inlet burial was followed by heaping quite a plenty of soil which resulted in that the tumulus became several times as large. The distinctive feature is that all the monuments are arranged along the watershed without visible clustering. The largest group is that of kurgans and burials referred to as the East Manych Catacomb culture. Catacomb barrows were inserted into the existing chain, and dimensionally the bulk of them were virtually identical to previous monuments.
\end{abstract}


Conclusions. The analysis shows research of Early and Middle Bronze Age burials should focus not only on quantitative properties in separate kurgans. When it comes to counting inlet burials it is critical to identify the cultural and chronological affiliation of the main burial. Moreover, it is important to obtain additional data, such whether the burial is located inside the tumulus or below the latter, whether there is any trace of later soil heaping, etc. This may be instrumental in discovering additional groups of inlet burials that vary from 'common' to 'elite' ones and could have been accompanied by several-fold enlargement of the initial (original) tumulus.

Keywords: main burial, inlet burial, additional soil heaping, Volga-Manych steppe, Ergeni Uplands, Bronze Age, Yamnaya culture, Early Catacomb culture, North Caucasian steppe culture, Pit-Catacomb group, East Manych Catacomb culture

Acknowledgements. The reported study was funded by government subsidy — project name 'Socio-Political and Cultural Development of South Russia's Peoples: a Comprehensive Research of Respective Processes' (state reg. no. AAAA-A19-119011490038-5).

For citation: Kekeev E. A. Elista Burial Mound Site: Analyzing the Correlation between Early and Middle Bronze Age Mounds and Burials. Oriental Studies. 2020. Vol. 13(3): 572-590. (In Russ.). DOI: $10.22162 / 2619-0990-2020-49-3-572-590$

\section{Введение}

Изучению погребальных памятников раннего и среднего бронзового века степей Юго-Восточной Европы в последние десятилетия посвящено несколько фундаментальных обобщающих исследований, в которых разрабатываются вопросы хронологии, рассматриваются особенности погребального обряда и материальной культуры. В работе В. Л. Державина на основе анализа элементов погребального обряда и инвентаря были выявлены основные обрядовые группы, которым соответствовали определенные группы древнего населения [Державин 1991]. Необходимо отметить, что в данной работе исследуются памятники степного Ставрополья, однако в процессе анализа отдельных обрядовых групп проведено сопоставление их с синхронными погребальными комплексами Кумо-Манычской впадины (курганные группы Восточного Маныча и Чограя) и Ергенинской возвышенности (курганные группы Аpхара, Элиста, Лола 1 и 2).

Работа А. В. Кияшко посвящена разработке концепции культурогенеза эпохи средней бронзы, исследование проведено на основе анализа материалов свыше двух тысяч погребальных комплексов с территории волго-уральских и волго-донских степей [Кияшко 2002].

В работе Н. И. Шишлиной впервые проведен подробный анализ материальной культуры и погребального обряда культур энеолита - раннего бронзового века Северо-Западного Прикаспия [Шишлина 2007].

В монографии М. А. Очир-Горяевой, представляющей собой свод источников археологических памятников, исследованных на территории волго-манычских степей (1929-1997 гг.), проведен статистический и пространственный анализ и выявлены различия в географическом распространении памятников бронзового века, с одной стороны, и памятников кочевников раннего железного века и средневековья - с другой [Очир-Горяева 2008].

В монографии М. В. Андреевой представлены результаты детального изучения восточноманычской катакомбной культуры, подробно описан погребальный обряд, предложена реконструкция некоторых черт социальной структуры носителей обряда [Андреева 2014].

В результате исследований Р. А. Мимохода часть материалов, ранее относимых к финалу восточноманычской катакомбной культуры, выделена в самостоятельную лолинскую культуру, часть блока посткатакомбных культурных образований [Мимоход 2013].

Благодаря этим фундаментальным исследованиям стало возможным по-новому взглянуть на материал, накопленный в результате крупных новостроечных археологических работ советского периода. В 1960-1970-е гг., в годы восстановления Калмыкии, в зонах хозяйственных объектов 
были исследованы не отдельные памятники, а целые курганные группы, состоящие из нескольких десятков насыпей. Большая часть результатов этих полевых работ была опубликована самими авторами раскопок, по их материалам проведены исследования отдельных категорий инвентаря и погребального обряда [Синицын 1978: 6-16; Эрдниев 1981: 3-24; Эрдниев 1982a: 73-111; Эрдниев 1982б: 3-23; и др.].

Именно из-за того, что основная часть материала опубликована и были написаны выше названные работы, сегодня имеется возможность рассмотреть соотношение курганов и погребений различных эпох в одной крупной курганной группе. Одним из таких памятников является курганная группа «Элистинский».
Целью данного исследования является анализ соотношения курганов и погребений культур раннего и среднего бронзового века среди памятников Элистинского могильника.

\section{Общая характеристика курганов Элистинский могильник}

Элистинский могильник является одним из самых крупных из изученных на территории Ергенинской возвышенности, и основное количество курганов и погребений датировано бронзовым веком: 23 из 37 курганов (62\%) и 92 из 123 погребений (75 \%) (рис. 1) (табл. 1). Остальные памятники датированы более поздними эпохами: три кургана и 12 погребений - ранний железный век; 11 курганов и 14 погребений - эпоха средневековья; 5 погребений не датированы.

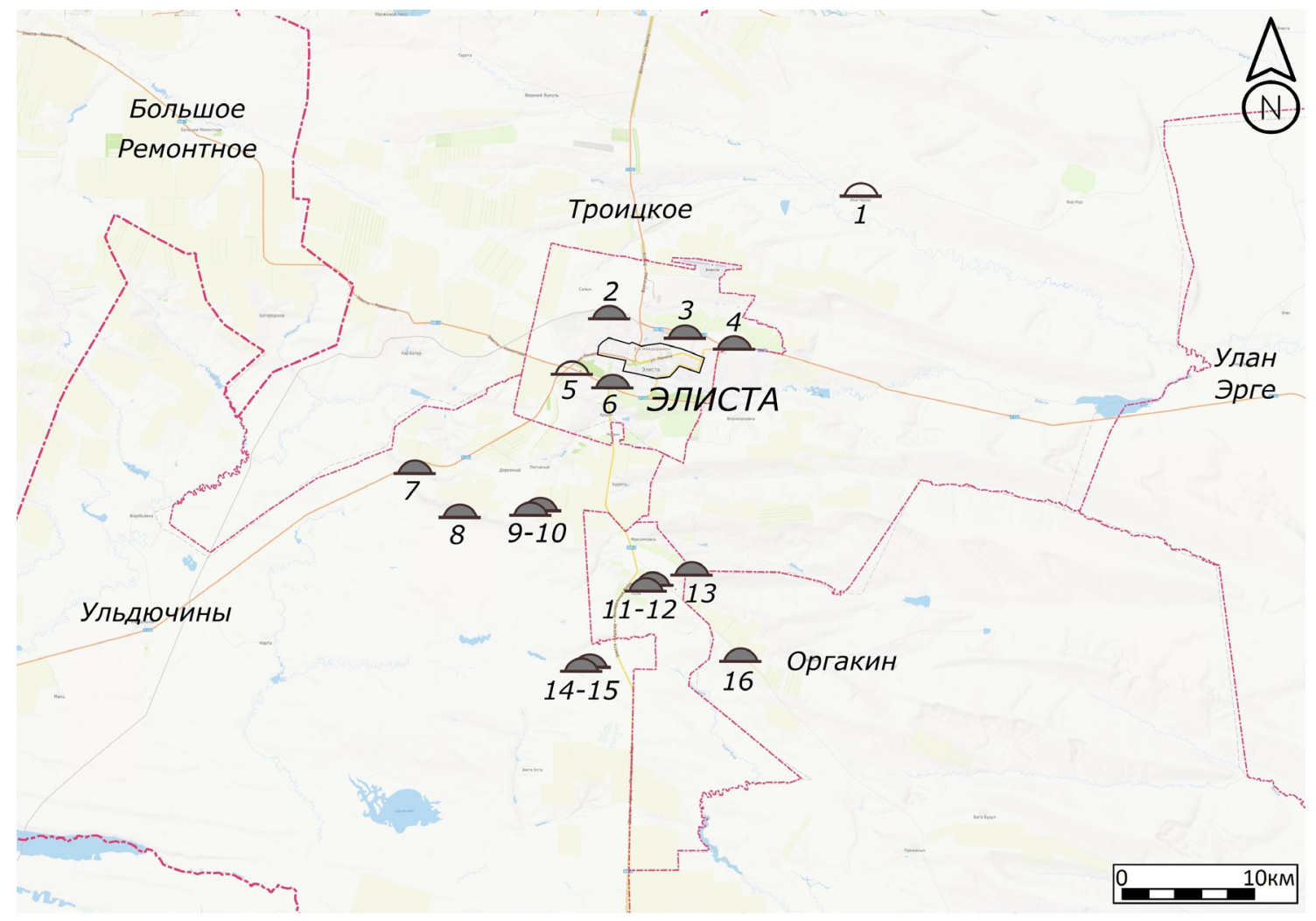

Puc. 1. Курганные могильники, исследованные на территории южной части Ергенинской возвышенности. Цифрами на карте обозначены: 1 - Чееря Хурул (1929); 2 - Элистинский (Элиста-3) (1964); 3 - Гашунский (1971); 4 - Элиста-1 (1929); 5 - Промзона (1997); 6 - Элиста-2 (1929); 7 - Бичкин Булук (1937); 8 - Цаган Эльсин (1937); 9 - Три Брата-1 (1933-1936, 1980); 10 — Три Брата-2 (1933-1936); 11 - Лола-1 (1961-1962); 12 - Лола-2 (1963); 13 - Архара (1962-1963); 14 — Хар Зуха (1991); 15 - Хар Зуха-2 (1991); 16 - Кермен Толга (1968-1970)

[Fig. 1. Investigated burial mound sites in the south of the Ergeni Upland: 1 - Chöörä Khurul (1929); 2 — Elistinsky (Elista-3) (1964); 3 - Gashunsky (1971); 4 - Elista-1 (1929); 5 — Promzona (1997); 6 Elista-2 (1929); 7 - Bichkin Buluk (1937); 8 - Tsagan Elsin (1937); 9 - Three Brothers-1 (1933-1936, 1980); 10 - Three Brothers-2 (1933-1936); 11 — Lola-1 (1961-1962); 12 — Lola-2 (1963); 13 - Arkhara (1962-1963); 14 — Khar Zukha (1991); 15 — Khar Zukha-2 (1991); 16 — Kermen Tolga (1968-1970)] 


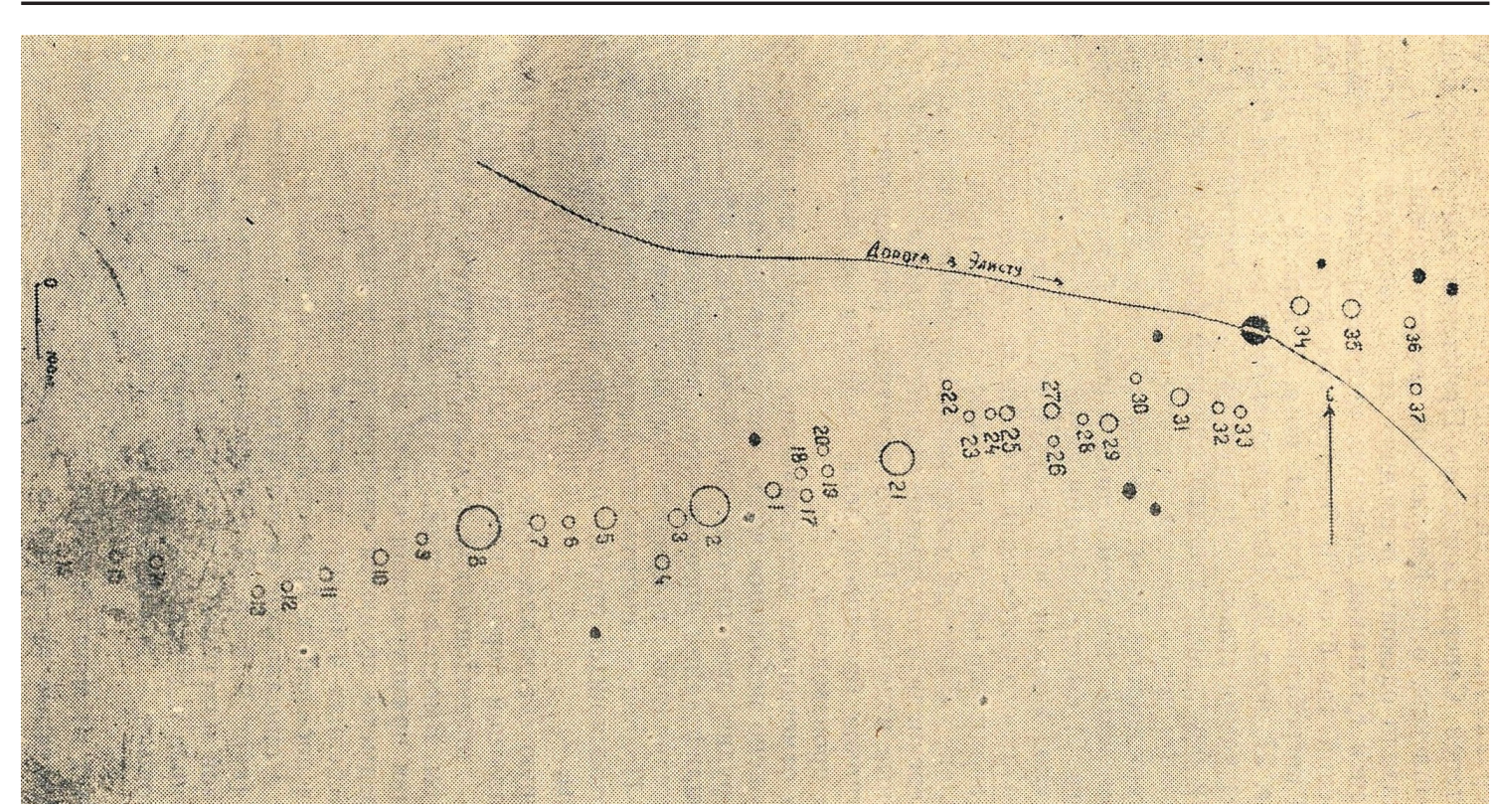

Puc. 2. Элистинский могильник. Оригинальный план [Синицын, Эрдниев 1971: рис. 1]

[Fig. 2. Elista grave field. Original site plan]

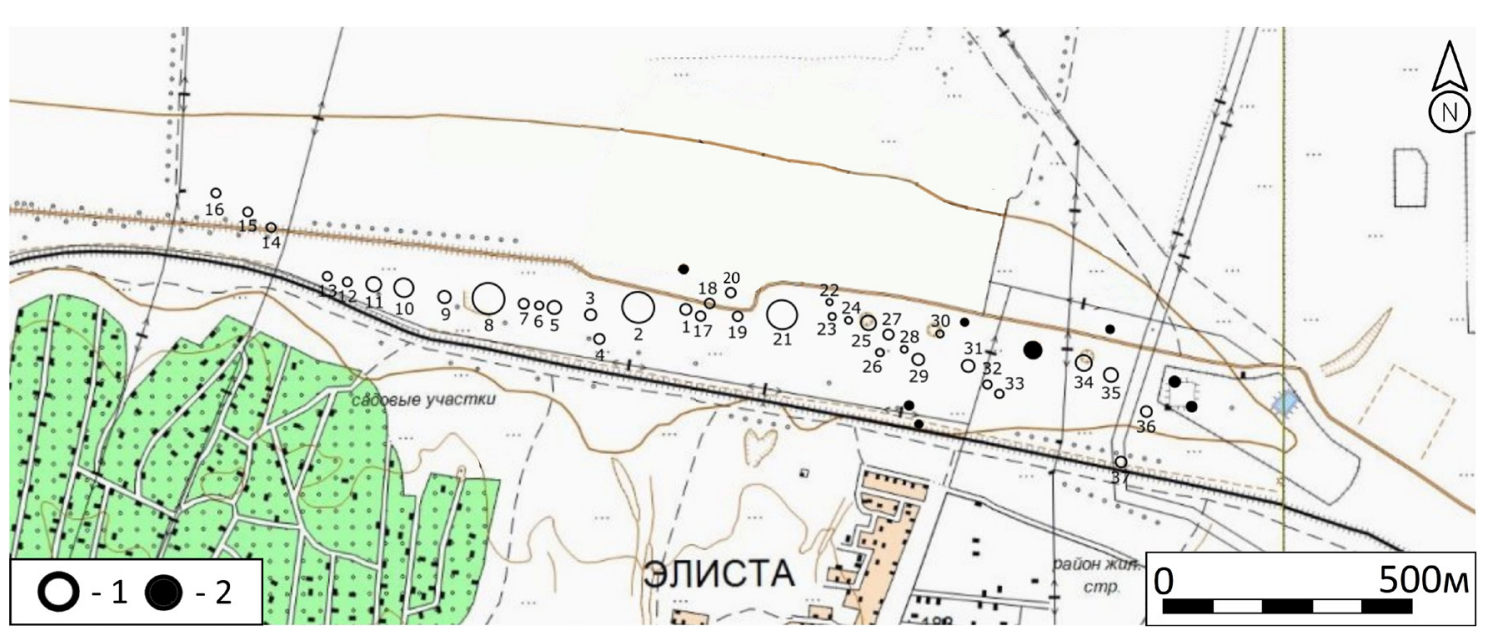

Puc. 3. Элистинский могильник. Местоположение на современной карте. Скорректированный план ( 1 - исследованные курганы, 2 - неисследованные курганы)

[Fig. 3. Elista grave field. Location according to the modern map. Updated site plan] ( 1 - investigated mounds, 2 - uninvestigated mounds)

Ергенинская возвышенность (от калм. эрг - берег, обрыв, яр) представляет собой платообразную возвышенность на юго-востоке европейской части России длиной около 300 км и шириной от 50 км в северной части до $350-$ в южной. Возвышенность имеет характерный эрозионный рельеф, образованный сочетанием плоских выровненных пространств и прорезающих их широких протяжных балок, которые вытянуты в широтном направлении, прямолинейны и обычно отдалены друг от друга расстоянием 5-10 км. С увеличением ширины возвышенности к югу увеличивается и протяженность этих балок, длина которых в южной части Ергенинской возвышенности достигает 20 км, ширина от 1 до 3 км, а глубина - более $100 \mathrm{M}$.

Восточный склон, в отличие от западного, расчленен более глубокими и крутосклонными балками, прорезан даже донными и склоновыми оврагами [Карандеева 1957; Спиридонов 1978: 231-234]. 
Характерной чертой курганных могильников Ергенинской возвышенности является линейное расположение насыпей - наиболее крупные группы представляют собой цепи курганов, расположенные на линии водоразделов, протянувшихся в широтном направлении. На платообразных гребнях встречаются группы, состоящие из нескольких параллельных цепей курганов [Шишлина 2007: 222-257; Очир-Горяева 2017: 397-404].

Насыпи курганной группы «Элистинский могильник» также расположены в виде единой цепи курганов, протянувшейся с запада на восток на расстояние 2 км. Большая часть могильника состояла из насыпей малого (диаметр 8-9 м, высота не более 1 м) и среднего размеров (диаметр 15-25 м, высота от 1 до 1,5 м), а в центре группы находилось три крупных кургана (диаметр до 60-70 м, высота до 6,5 м). Спасательные раскопки были связаны со строительством железной дороги Дивное - Элиста, археологические раскопки были проведены в 1964 г., работами руководили И. В. Синицын и У. Э. Эрдниев. Результаты были опубликованы в виде монографии «Элистинский курганный могильник» [Синицын, Эрдниев 1971].

Следует сказать, что, судя по современным данным, курганная группа имеет продолжение [Буваев 2009: 3-11]. Цепь из 24 курганов протянулась на запад, с небольшим отклонением к северу: 13 курганов малого (диаметр 12-15 м, высота до 1 м), 3 кургана - среднего (диаметр 12-16 м, высота $1-1,4$ м) и 3 кургана - крупного размеров (диаметр 30-36 м, высота 2,3-4 м) [Буваев 2009: табл. 1]. Размеры пяти курганов не установлены [Буваев 2009: рис. 4]. Общая протяженность всей курганной группы, насчитывавшей до спасательных раскопок 61 насыпь, составляла 4,7 км.

За полевой сезон 1964 г. в могильнике исследовано 37 курганов, обнаружено 123 разновременных погребения [Синицын, Эрдниев 1971: 3-4]. В данном могильнике бронзовым веком было датировано 23 кургана и 92 погребения: ямная культура - 2 кургана, 2 погребения; ранняя катакомбная культура -4 кургана, 6 погребений; степная северокавказская культура - 6 курганов, 10 погребений; ямно-катакомбная группа - 3 погребения; восточноманычская катакомбная культура (восточноманычский вариант катакомбной культуры) (далее - ВМКК) - 11 курганов, 71 погребение (табл. 2).

Для анализа взаиморасположения курганов оригинальный план Элистинского могильника (рис. 2) [Синицын, Эрдниев 1971: рис. 1] был сверен с современными картами из общедоступных сервисов GoogleEarth и SASPlanet. По причине того, что большая часть курганов не была рекультивирована после раскопок, на современных фотоснимках четко фиксируются следы проведенных раскопок, особенно заметны остатки крупных курганов. Была проведена работа по локализации объектов на местности и точном позиционировании группы курганов на современной карте (рис. 3). В результате данного этапа выяснилось, что, судя по оригинальному плану, цепь курганов располагалась на линии запад-восток, с отклонением западного края к югу, а восточного к северу. Однако совмещение этого плана с объектами на местности показало, что цепь имела другой угол относительно линии запад-восток: западный край отклонялся к северу, а восточный — к югу (рис. 4).

Элистинская курганная группа формировалась в течение длительного времени, который охватывает периоды: ямная, раннекатакомбная и степная северокавказская культуры, группа ямно-катакомбных погребений, восточноманычская катакомбная культура (восточноманычский вариант катакомбной культуры). Именно в таком стратиграфическом порядке были зафиксированы погребения в отдельных курганах Элистинского могильника.

Соотношение курганов и погребений в могильнике

Для выявления соотношения курганов и погребений рассмотрены расположение и особенности устройства насыпей каждой культурно-хронологической группы. Основным обьектом изучения были основные погребения. Для впускных погребений приведены данные об их местоположении в кургане относительно основного погребения, отмечены случаи нарушения основного погребения впускным. Поло-возрастные определения даются по данным авторов раскопок [Синицын, Эрдниев 1971].

Отдельно рассмотрены два наиболее крупных кургана, насыпи которых были сооружены в три этапа. Оба кургана были 


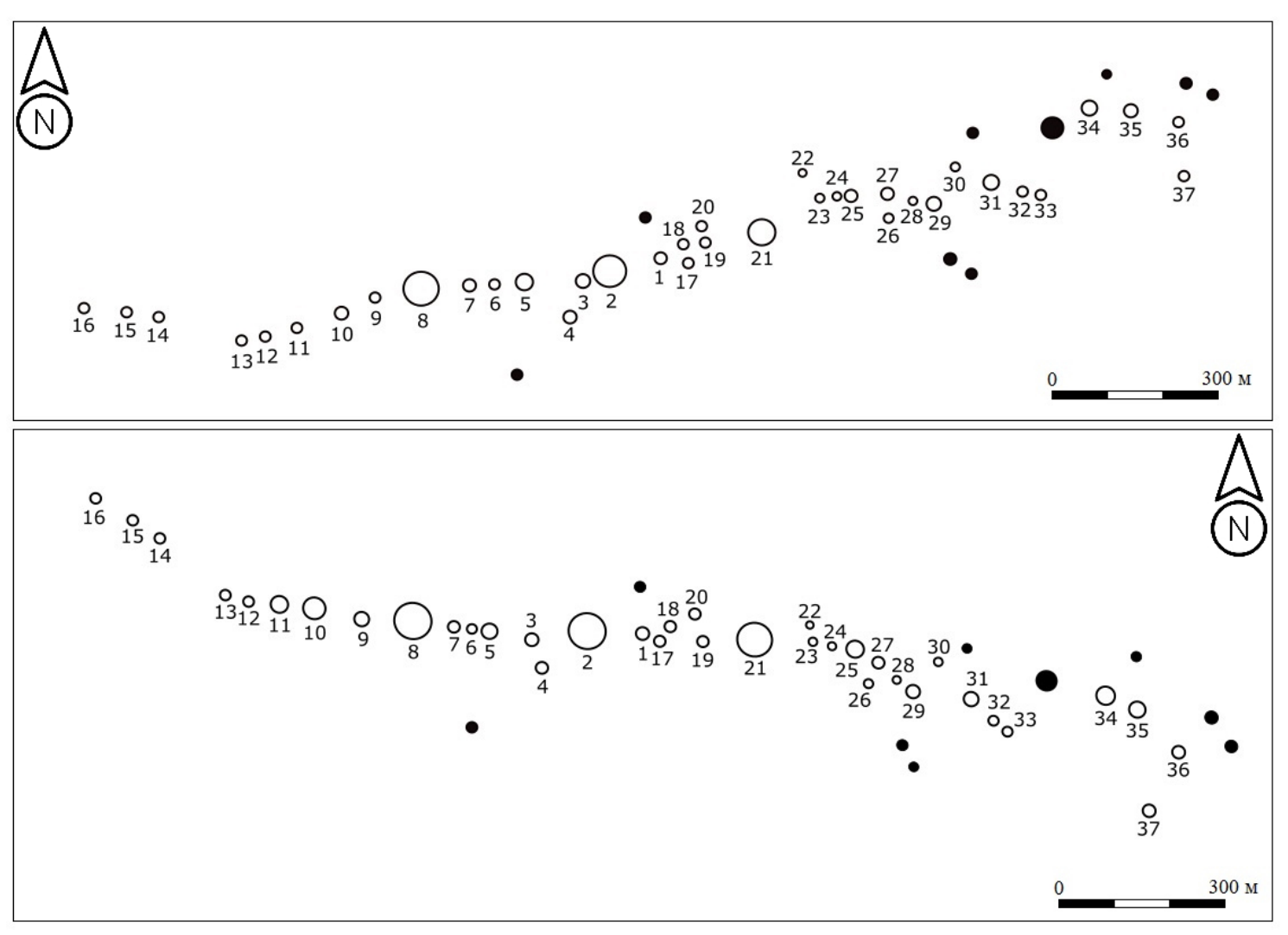

Puc. 4. Элистинский могильник. Оригинальный и скорректированный планы памятника [Fig. 4. Elista grave field. Original and updated site plans]

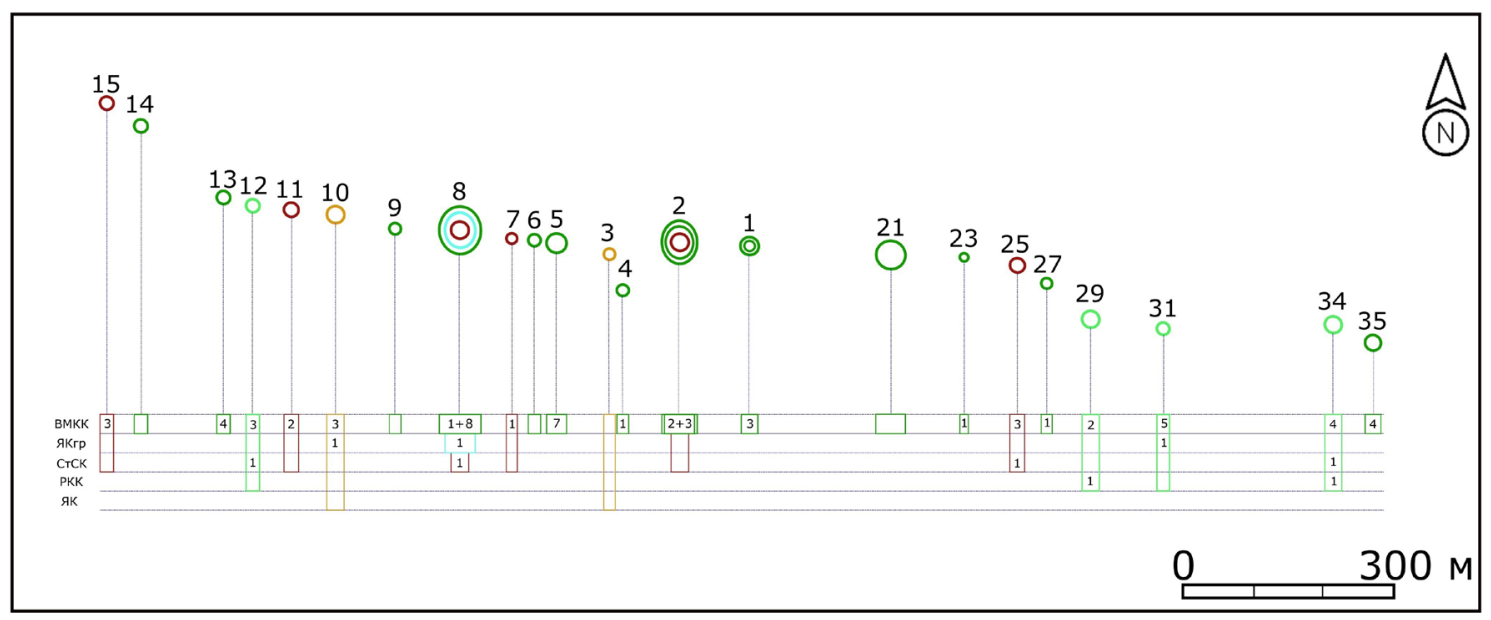

Puc. 5. Элистинский могильник. Культурно-хронологическая принадлежность курганов и погребений (1 - ямная культура; 2 - ранняя катакомбная культура; 3 - степная северокавказская культура; 4 - ямно-катакомбная группа; 5 - восточноманычская катакомбная культура) (Цифрой обозначено количество погребений, в случае досыпки кургана: первая цифра — количество погребений до досыпки, вторая - после)

[Fig. 5. Elista grave field. Archaeological cultures and chronologies of mounds and burials (1 - Yamnaya culture; 2 - Early Catacomb culture; 3 - North Caucasian steppe culture; 4 - Pit-Catacomb group; 5 East Manych Catacomb culture) (Figures indicate numbers of burials in case of later soil heaping: figure one - number of burials in the original kurgan, figure two — total one thereafter)] 
насыпаны представителями степной северокавказской культуры и имели довольно крупные размеры (диаметр 25-30 м, высота 1,75-2 м). Курган 2 подвергся двум значительным досыпкам после сооружения погребений восточноманычской катакомбной культуры. Вторая насыпь кургана 8 была сооружена после совершения погребения ямно-катакомбной группы, третья связана с погребением восточноманычской катакомбной культуры.

В изучаемом могильнике самыми древними были курганы ямной культуры. Всего насчитывается две насыпи: курган 3 (диаметр 16 м, высота 0,85 м) и курган 10 (диаметр 23 м, высота 2,1 м), которые были расположены практически на линии западвосток, на значительном отдалении друг от друга (370 м) (рис. 5 ; рис. 6,1$)$. В обоих курганах обнаружено по одному основному погребению ямного времени, без однокультурных впускных (рис. 8). В кургане 3 было исследовано безынвентарное мужское погребение [Синицын, Эрдниев 1971: 55].

В кургане 10 основное погребение ямного времени было разрушено, в процессе его изучения зафиксированы кости взрослого человека, сопровождающий инвентарь в виде круглодонного глиняного сосуда и кремниевой пластины. Грабительский раскоп также нарушил часть восточноманычского погребения 3 , расположенного в непосредственной близости от центра кургана, на уровне погребенной почвы [Синицын, Эрдниев 1971: 79].

Из этого следует, что основное погребение было разрушено скорее с целью ограбления, нежели причины данного проникновения были связаны с сакральными действиями. Всего в курган 10, который был больше кургана 3, было впущено четыре погребения (одно - ямно-катакомбное, три - восточноманычских).

Следующими по хронологии являются памятники раннекатакомбной культуры, в этот период было сооружено четыре кургана $(12,29,31$ и 34). Размеры этих курганов по сравнению с двумя насыпями ямной культуры не выделялись своими размерами: диаметр - от 16 до 24 м, высота - от 1 до 2,35 м (рис. 7). Описывая их расположение, отметим, что курган 12 сооружен западнее кургана 10 (ямная культура), а остальные три (29, 31 и 34) находились восточнее кургана 3 (ямная культура) на расстоянии более 650 м от него и в какой-то степени представляли собой обособленную группу памятников (рис. 5 ; рис. 6,2 ).

Второй особенностью памятников раннекатакомбной культуры является то, что они совершали впускные погребения только в насыпи собственных курганов (29 и 34) (рис. 8). В курганах 12 и 29 основными являлись мужские погребения, в кургане 31 - основное погребение было разрушено, отмечены кости взрослого человека, а в кургане 34 было обнаружено парное погребение мужчины и женщины.

В двух впускных погребениях были погребены подросток (курган 29, погребение 4) и ребенок 4-5 лет (курган 34, погребение 7). Возможно, эти впускные погребения были совершены по единому ритуалу: оба расположены к северо-востоку от основного погребения (на расстоянии 2,5 и 6 м), в материке, оба безынвентарны.

Памятники степной северокавказской культуры представляли собой курганы, которые были равномерно распределены по могильнику без видимых скоплений (курганы 2, 7, 8, 11, 15 и 25), можно лишь выделить курганы 7 и 8 , находящиеся рядом друг с другом на расстоянии 50 м. Эти шесть курганов встраивались в единую цепочку с насыпями ямной и раннекатакомбной культур и образовали «костяк» изучаемого могильника (рис. 6, 3).

Насыпи четырех курганов $(7,11,15$ и 25) не выделялись своими размерами и укладывались в следующий диапазон: диаметр - от 13 до 21 м, высота — от 0,85 до 1,35 м (рис. 7). Размеры двух курганов (2 и 8) были выявлены только в результате раскопок, так как эти насыпи были увеличены путем совершения значительных досыпок в более позднее время. Судя по реконструированным размерам, эти курганы были самыми большими среди насыпей степной северокавказской культуры: курган 2 (диаметр 30 м, высота 2 м) и курган 8 (диаметр 25 м, высота 1,5 м). А среди памятников трех вышеописанных культур это были самые большие курганы в диаметре и в высоту уступали только двум близким по размерам курганам: ямный курган 10 (диаметр 23 м, высота 2,1 м) и раннеката- 

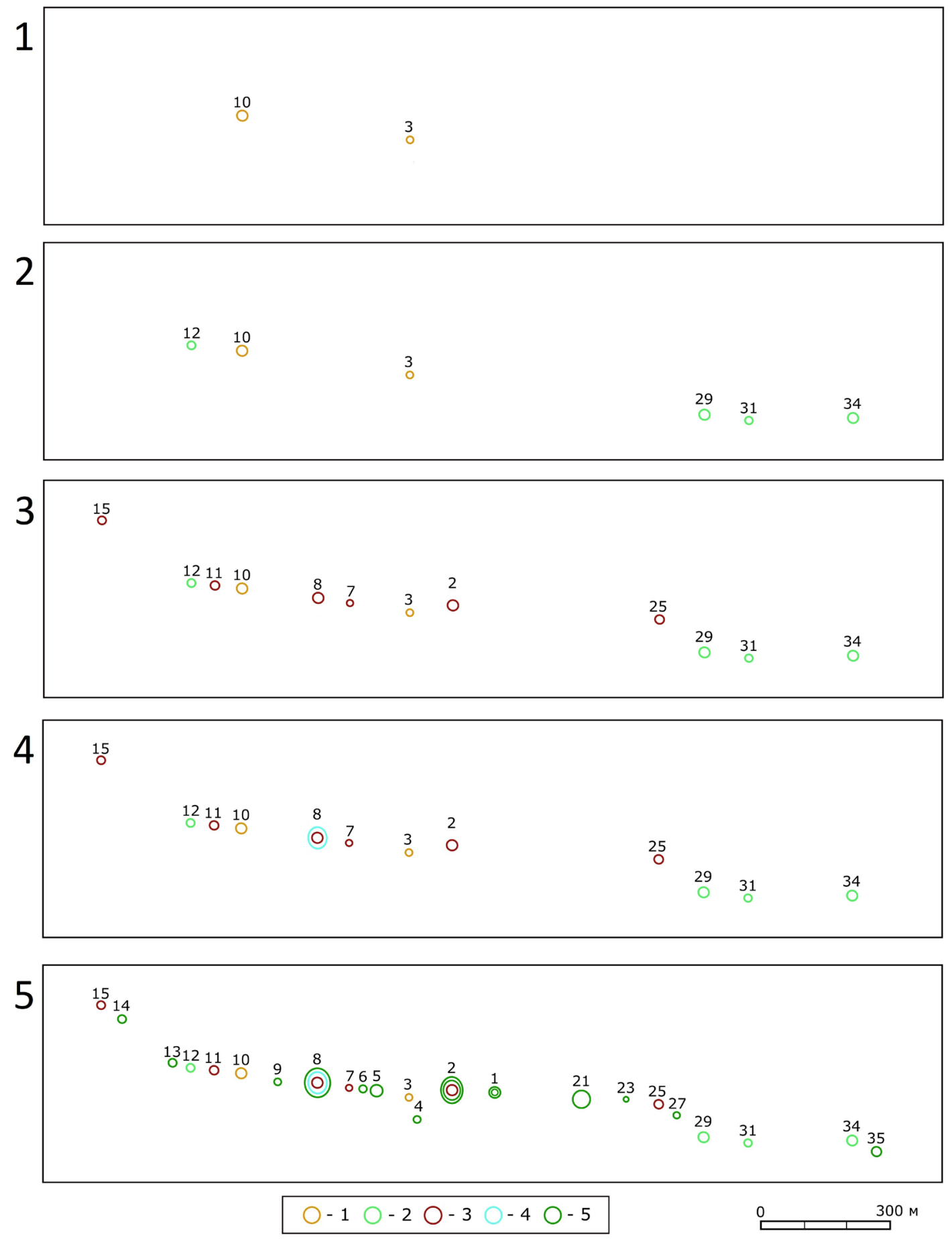

Puc. 6. Планиграфия Элистинского могильника: 1 - ямная культура; 2 - ранняя катакомбная культура; 3 - степная северокавказская культура; 4 - ямно-катакомбная группа; 5 восточноманычская катакомбная культура

[Fig. 6. Planigraphy of the Elista grave field: 1 - Yamnaya culture; 2 - Early Catacomb culture; 3 North Caucasian steppe culture; 4 - Pit-Catacomb group; 5 - East Manych Catacomb culture] 

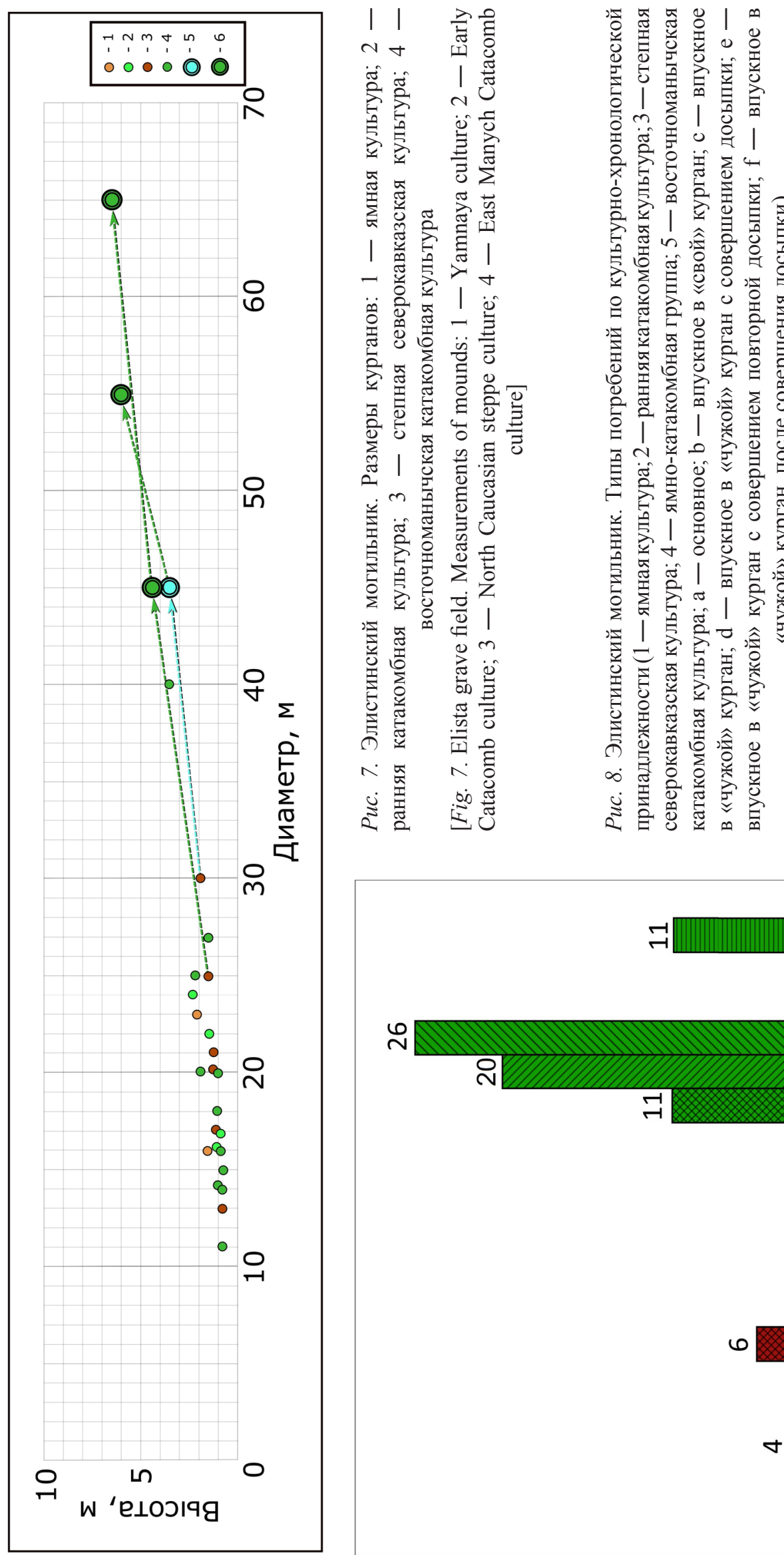

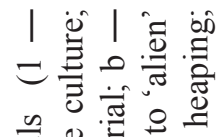

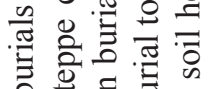

量管空

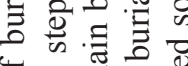

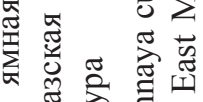

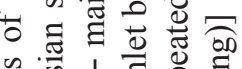

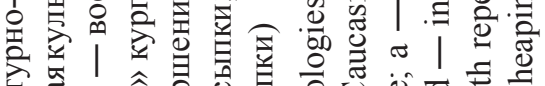

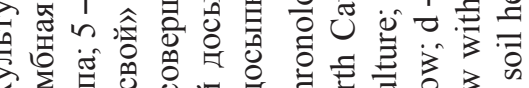

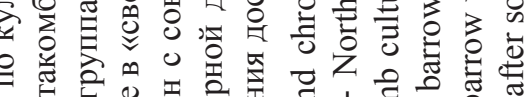

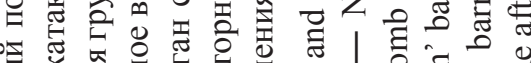

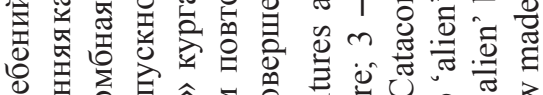

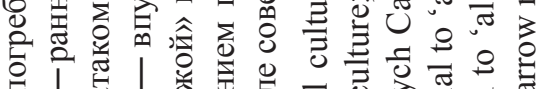

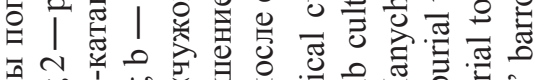

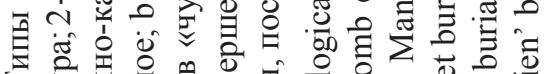

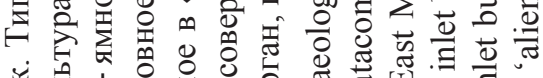

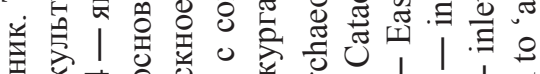

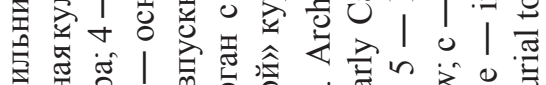

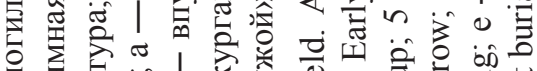

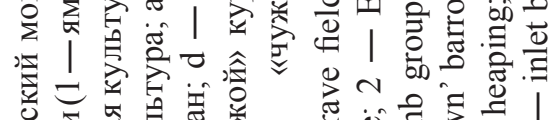

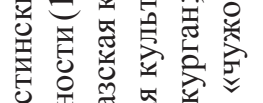

$\sum \sim$ का

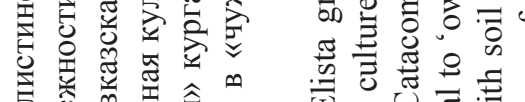

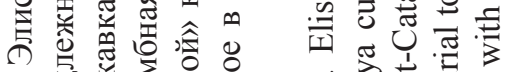

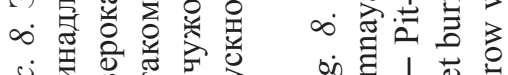

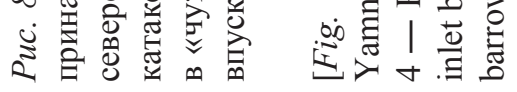

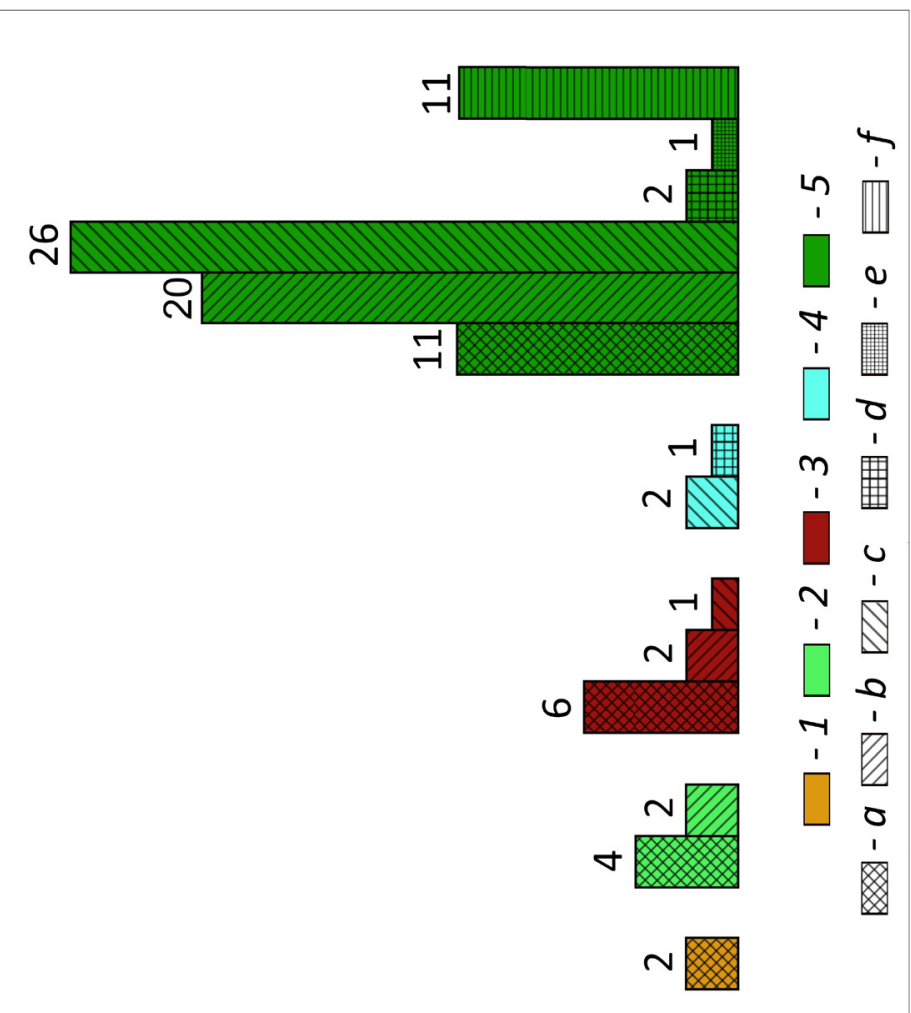


комбный курган 29 (диаметр 24 м, высота 2,35 м). Возможно, одной из причин выбора именно этих курганов для создания новых насыпей являлся их размер.

Во всех шести основных погребениях были обнаружены индивидуальные захоронения взрослых людей, в том числе три мужских костяка (рис. 5). В курганы своей культуры (8 и 25) было впущено по одному индивидуальному погребению взрослых людей, в одном из которых зафиксирован женский костяк (рис. 8). Оба погребения обнаружены в материке, одно в юго-западном секторе (курган 8, погребение 9), второе (женское погребение) - в северо-восточном (курган 25, погребение 5).

Кроме этого, два парных погребения (мужчина и женщина) были впущены в курганы раннекатакомбной культуры (12 и 34). Общим для этих погребений является их стремление быть расположенными несколько севернее центра кургана, однако одно (курган 12, погребение 4) было совершено в материке, на глубине один метр ниже уровня погребенной почвы, а второе (курган 34 , погребение 4) было обнаружено в насыпи на глубине 0,85 м от поверхности кургана. Отметим, что в процессе создания погребения в кургане 12 была нарушена верхняя часть основного погребения, однако камера не была повреждена, так как глубина достигла только одного метра, и само погребение осталось не тронутым.

Еще один хронологический горизонт образуют погребения ямно-катакомбной группы [Шишлина 2007: 197-218]. Представителями данной группы не сооружалось отдельных курганов, индивидуальные погребения совершались под насыпями существующих курганов, в материке (рис. 5; рис. 6, 4, рис. 8). Останки погребенных принадлежали взрослым людям (пол одного погребенного - мужской). В кургане 10 ямного времени погребение данной группы обнаружено в северо-восточном секторе, в 6 м от основного погребения. В раннекатакомбном кургане 31 погребение ямно-катакомбной группы было сооружено в центре насыпи и нарушило входную шахту основного погребения. Хотя сама камера основного погребения, судя по чертежу [Синицын, Эрдниев 1971: рис. 61], не была повреждена, основное погребение было разграблено, отмечены отдельные кости взрос- лого человека, разбитый глиняный сосуд и каменная зернотерка [Синицын, Эрдниев 1971: 96].

Для погребений ямно-катакомбной группы не создавалось собственных насыпей, однако для одного из них была совершена значительная досыпка существующего кургана. Первая насыпь кургана 8 (степная северокавказская культура) после создания впускного погребения 8 была значительно увеличена, диаметр возрос с 25 м до 40-50 м, а высота - с 1,5 м до 3,5 м (рис. 7). Судя по чертежу, изменилась и форма насыпи - с округлой в плане на овальную. Так как погребение было совершено в южной части существующей насыпи, несколько восточнее центральной оси север-юг, после столь значительной досыпки центр кургана был смещен к югу. Отметим, что само погребение и по ритуалу, и по конструкции идентично двум остальным погребениям ямно-катакомбной группы.

Следующей и наиболее многочисленной группой курганов и погребений в изучаемом могильнике являются памятники восточноманычской катакомбной культуры, которых насчитывается 71 погребение и 13 курганов (курганы 2 и 8 - памятники степной северокавказской культуры, которые были подвергнуты значительным досыпкам в катакомбное время). Все курганы встраивались в общую, уже существующую, цепь и сформировали окончательный вид могильника в бронзовом веке (рис. 5; рис. 6, 5).

Большая часть курганов восточноманычской катакомбной культуры не выделялась своими размерными данными. 8 курганов $(4,6,9,13,14,23,27,35)$ были в диаметре от 11 до 20 м и высотой от 0,75 до 1,5 м. Более крупные курган 1 (диаметр 25 м, высота 2,25 м) и курган 5 (диаметр 27 м, высота 2,25 м) были почти самыми крупными среди всех (без учета курганов 2, 8 и 21), включая более ранние курганы (рис. 7). По информации из отчета курганы 1 и 5 подвергались небольшим досыпкам после совершения в них отдельных погребений [Синицын, Эрдниев 1971: 41, 71].

Среди курганов, созданных без следов досыпок, выделялся манычский курган 21, насыпь которого была диаметром 40 м и в высоту достигала 3,5 м, в нем содержалось единственное погребение в каменном ящике. Погребения подобного типа являются 
крайне редкими, и они более характерны для памятников Ставропольской возвышенности [Андреева 2014: 22; Державин 1984]. Сам курган внешне выделялся среди памятников не только своими размерами, но и тем, что вся его поверхность была покрыта камнем.

Два самых крупных кургана в группе были созданы за счет досыпок существующих насыпей, их финальные размеры сделали их самыми большими в изучаемом могильнике - диаметр до 70 м, высота до 6-6,5 м.

Первым объектом является третья насыпь кургана 8, первая из которых была создана над погребением степной северокавказской культуры, а вторая - представителями ямно-катакомбной группы (описано выше). Отметим, что вторая насыпь на тот момент уже была самой большой в группе (диаметр 40-50 м, высота 3,5 м). После впущенного в нее катакомбного погребения 6 была создана финальная насыпь (диаметр 60-70 м, высота до 6,5 м).

Погребение 6, как и размеры связанной с ним третьей насыпи кургана 8, выделялось среди остальных погребений своим разнообразным инвентарем. Парное погребение женщины и ребенка находилось внутри кузова деревянной четырехколесной повозки с хорошо сохранившимися колесами. Многочисленный инвентарь состоял из изделий из золота, бронзы, глины, камня и т. д. Необходимо отметить, что данное погребение не является единственным подобным в данном кургане: погребение 7, являющееся кенотафом и открытое в трех метрах к северу от описанного погребения, также содержало деревянную четырехколесную повозку. [Синицын, Эрдниев 1971: 74-75].

Кроме того, с погребением-кенотафом связан жертвенник, состоящий из черепов и костей ног семи особей крупного рогатого скота (далее - КРС), уложенных над повозкой в насыпи. Подобные жертвенные комплексы с таким количеством останков КРС являются довольно редкими среди памятников раннего и среднего бронзового века [Кекеев 2018; Кекеев 2019]. Только после создания третьей насыпи в курган были впущены восемь погребений восточноманычской катакомбной культуры, два из которых были материковыми.
Курган 2 состоял из трех насыпей, первая из которых была построена над погребением степной северокавказской культуры, затем было создано две насыпи восточноманычской катакомбной культуры. В существующем кургане не содержалось погребений, кроме основного, первым в него было впущено катакомбное погребение 7. После досыпки изменилась и форма кургана, которая была округлой в плане, а стала овальной, вытянутой с юга на север. Диаметр увеличился с 30 до 40 м (по линии запад-восток) и на 50 м (по линии северюг), а высота - с 2 до 4-4,5 м. Досыпка была связана с мужским погребением со скудным инвентарем, однако с прослеженным деревянным перекрытием и циновкой, на дне были исследованы столбовые ямки, предположительно являющиеся остатками шатрового сооружения [Синицын, Эрдниев 1971: 45-46].

Следующим в данный курган было впущено погребение 8, после сооружения которого насыпь была увеличена в диаметре до 50 м (по линии запад-восток) и до 60 м (по линии север-юг), а высота увеличилась до 6 м. Погребение 8, как и предыдущее погребение, содержало следы циновки и столбовые ямки, в нем было исследовано парное погребение женщины и ребенка с богатым инвентарем, изготовленным из глины, бронзы и камня [Синицын, Эрдниев 1971: 46-53]. После совершения финальной досыпки в насыпь кургана было впущено три погребения восточноманычской катакомбной культуры и создан один жертвенный комплекс с останками двух особей КРС.

Рассмотрим, как распределились 71 впускное погребение ВМКК в «своих» курганах и в курганах других культур. 11 впускных погребений исследовано в описанных выше курганах - 2 и 8. В остальных 11 курганах катакомбной культуры было впущено 20 погребений, а в девять «чужих» - 26 (рис. 8). Интересным является тот факт, что в инокультурных курганах количество впускных погребений не зависело от размеров насыпи. В курганах же восточноманычской катакомбной культуры наблюдается эта зависимость - количество впускных погребений прямо пропорционально размерам насыпи кургана.

Перед анализом их взаиморасположения отметим одну характеристику, важную 
для данного этапа исследования, - размещение впускного погребения в материке или в насыпи. По данным М. В. Андреевой, есть существенные различия между этими видами впускных погребений, в том числе выявлен факт того, что материковые погребения чаще обладают большей «престижностью» [Андреева 2014: 63].

Как указано выше, в девять курганов других культур (ямная, степная северокавказская и раннекатакомбная) было впущено 26 погребений, то есть почти 3 погребения на курган (от 1 до 5). Из них только 11 было совершено в материке - 1,2 материкового погребения / курган. Причем этот показатель никогда не превышал двух материковых погребений в одном кургане. Следов досыпок не отмечено.

Курганы восточноманычской катакомбной культуры можно поделить на три группы в соответствии с размерами их насыпи. В результате рассмотрения основных показателей, выявлены структурные различия памятников этих групп.

Первая группа - курганы ВМКК малых размеров (диаметр от 11 до 18 м, высота от 0,75 до 1,1 м), в них было обнаружено только три впускных погребения, в трех курганах по одному, а три кургана были вообще без впускных погребений (средний показатель - 0,5 погребения / курган). Лишь одно впускное погребение было совершено в материке, детское погребение нарушило основное женское, однако, как будет описано ниже, есть вероятность, что этот случай является примером преднамеренного действия [Андреева 2014: 63]. Если это так, получается, что в курганах этой группы все впускные погребения (два) находились в насыпи. Следов досыпок не выявлено.

Вторая группа - курганы 13 и 35, 7 впускных погребений ВМКК, 3,5 погребения / курган (диаметр 20 м, высота от 1,151,5 м). В обоих курганах выявлено только по одному впускному материковому погребению. Следов досыпок не отмечено.

Третья группа - курганы 1 и 5, 10 впускных погребений ВМКК, 5 погребений / курган, (диаметр 25-27 м, высота от 1,5 до 2,25 м). В кургане 1 после основного погребения было впущено два материковых погребения и последним было совершено материковое погребение 2, после которого курган был досыпан. В кургане 5 до досып- ки имелось основное и впускное материковое погребения, затем было сооружено три погребения в материке, совершена досыпка, и насыпь приобрела свои окончательные размеры. Еще три впускных погребения были созданы позже в насыпи кургана без совершения досыпки. В курганы этой группы суммарно было впущено 7 материковых погребений.

В результате проведенного анализа выявлены основные отличия в устройстве внутрикурганного пространства памятников (курганов малого и среднего размеров), имеющих впускные погребения восточноманычской катакомбной культуры. В «чужих» курганах среднее количество впускных погребений ВМКК выше, чем в катакомбных курганах. Их количество в отдельных курганах не зависит от размера насыпи. Однако только 11 из 26 погребений совершено в материке. Инокультурные курганы не подвергались досыпкам. В собственно катакомбных курганах количество впускных погребений прямо пропорционально размерам насыпи. Возможно, при сооружении курганов малых размеров не предполагалось создание впускных погребений. Курганы вышеописанной второй группы изначально были средних размеров и допускали создание нескольких впускных погребений, досыпок прослежено не было. Курганы третьей группы (среднего размера), возможно, изначально относились к курганам первой или второй группы, и после создания материковых впускных погребений их насыпи были увеличены.

Особняком стоит вышеописанный курган 21, выделяющийся своими размерами и своей конструкцией, однако не имевший впускных погребений. В самые крупные курганы (2 и 8), конструкции которых описаны выше, было впущено 11 погребений (в среднем 5,5 погребений / курган). Как указано ранее, в кургане 2 обнаружено только три впускных погребения, и все они располагались в насыпи. В кургане 8 только два впускных погребения из восьми были материковыми.

В курганах восточноманычской катакомбной культуры большая часть основных погребений являлась захоронениями взрослых людей, 10 погребений были индивидуальными, 3 - парными, 1 - кенотаф. В индивидуальных погребениях в пяти случаях были зафиксированы останки мужчин, в 
четырех обнаружены женские захоронения, в одном - погребение подростка. Все три парных погребения содержали останки женщины и ребенка. Отметим, что большие по объему вторая насыпь кургана 2 и третья насыпь кургана 8 были созданы над парными погребениями.

Отметим некоторые особенности, выявленные в результате изучения соотношения впускных погребений в «свои» и в «чужие» курганы. В курганы других культур катакомбники не совершали детских погребений, обнаружен только один кенотаф, и только одно погребение было парным (женщина и ребенок), все остальные 24 были индивидуальными. В трех исследованы погребения подростков, в 21 - погребения взрослых людей, в том числе одно мужское и пять женских захоронений.

Как указано выше, в собственные насыпи катакомбники совершили 31 погребение, пять из которых являлись кенотафами, и только одно было парным (женщина и ребенок). В остальных 25 индивидуальных погребениях исследованы захоронения детей (4 погребения), подростков (4 погребения) и взрослых людей (17 погребений), в том числе 3 мужских и 2 женских.

Основное количество впускных погребений - как в однокультурных, так и в курганах других культур - было захоронениями взрослых людей. Отметим, что в инокультурных курганах катакомбники не хоронили детей, и только один кенотаф из пяти был сооружен под насыпью кургана степной северокавказской культуры.

Распределение по секторам в курганах других культур впускных катакомбных погребений следующее: основная нагрузка легла на центр кургана и на его восточную половину - 17 из 26 погребений, особенно заметно количество погребений в юго-восточном секторе - 10. Тринадцать погребений совершено в материке, а вторая половина — в насыпи курганов.

В однокультурных курганах катакомбные погребения распределены между секторами более равномерно, наблюдается некоторая тяга к центру, однако большая часть погребений, близких к центру кургана, совершена в его насыпи. 11 погребений из 31 было совершено в материке, из которых 4 - кенотафы, одно - погребение подростка, 4 - погребения взрослых людей, в том числе одно мужское и два женских, а два - парные погребения женщины и ребенка. Отметим, что все 4 детских погребения были совершены в центральной части насыпи кургана, выше уровня погребенной почвы.

Выделяется тот факт, что впускные катакомбные погребения подростков, как в однокультурных курганах, так и в курганах других культур, имеют схожие черты: два погребения было сооружено в северо-восточном секторе, они находились в материке, а в юго-западном секторе исследовано пять подростковых погребений, и все они были совершены в насыпи кургана, то есть выше уровня погребенной почвы.

Рассматривая подробно характер использования катакомбниками подкурганного пространства памятников других культур, необходимо отметить, что только одно из 26 впускных погребений частично нарушило основное погребение. В кургане 25 основным было погребение 4 степной северокавказской культуры, его небольшая юго-восточная часть была срезана в результате создания восточноманычского погребения 5 [Синицын, Эрдниев 1971: 91, рис. 55]. В остальных же случаях, даже когда погребение находилось в непосредственной близости к центру кургана и совершалось в материке, основные погребения не были потревожены.

В однокультурных курганах катакомбники так же не нарушали основные погребения. Отмечен один случай в кургане 27 , когда при создании детского катакомбного погребения 1 была нарушена входная шахта основного женского погребения 2. В результате камера детского захоронения находилась в засыпи входной шахты женского, что, учитывая принадлежность этих погребений к одной культуре, могло быть сделано умышленно [Андреева 2014: 65].

Подобный случай исследован в кургане 12 группы 2 могильника «Восточный Маныч» (левый берег), яму основного погребения взрослого человека перекрывала входная шахта катакомбы подросткового погребения [Синицын 1978: 73]. Есть мнение о том, что подобные погребения являются показателями близкого родства между погребенными [Андреева 2014: 65].

Интересен один случай, когда одно восточноманычское впускное погребение нару- 
шило другое впускное захоронение ВМКК. В кургане 12 реннекатакомбной культуры было впущено катакомбное погребение 2 (взрослый человек) в северо-восточном секторе, ближе к центру кургана. Это погребение было разрушено в результате создания погребения 3 (женщина и ребенок). Судя по отчету, погребение 3 было сооружено во входной шахте погребения 2. Однако размеры создаваемого погребения были больше, и в процессе его создания у погребенного, находящегося в камере, была срезана верхняя часть скелета вплоть до грудной клетки. Обнаруженное погребение не остановило его устроителей, и они продолжили, в результате было создано погребение в форме ямы на 0,2 м глубже уровня пола камеры поврежденного погребения 2 [Синицын, Эрдниев 1971: 81, рис. 39].

В результате проведенного анализа видно, что катакомбники относились к основным погребениям в курганах других культур так же, как и к основным погребениям в «своих» курганах, то есть старались их не нарушать. Из 26 погребений в инокультурных курганах только в одном случае было незначительно повреждено основное погребение. Из 31 погребения, впущенного в однокультурные курганы, только одно нарушило основное погребение, что, судя по всему, было сделано умышленно.

\section{Выводы}

Самыми ранними памятниками Элистинского могильника являлись курганы и погребения ямной и раннекатакомбной культур. Два кургана ямной культуры содержали только по одному основному погребению (индивидуальные погребения взрослых людей). В двух из четырех курганов раннекатакомбные погребения обнаружены: по одному впускному — одно детское и одно подростковое погребения. В основных погребениях, как и в ямных курганах, исследованы останки взрослых людей.

С обнаружением памятников степной северокавказской культуры появилась возможность изучить характер использования древним населением не только подкурганного пространства «своих» курганов, но и как были устроены впускные погребения в инокультурных памятниках. Все основные и впускные раннекатакомбные погребения являлись захоронениями взрослых людей, в однокультурные курганы впущены индивидуальные погребения, а в двух «чужих» создано по одному парному погребению мужчины и женщины. Причем впущенные в инокультурные курганы погребения располагались в материке, к северу от центра, в непосредственной близости от него, но при их устройстве целостность основного погребения не была нарушена.

Памятники ямно-катакомбной группы немногочисленны, всего три погребения. Однако при их изучении перед нами предстает совершенно другой характер использования инокультурного подкурганного пространства. Так при устройстве впускного погребения в кургане раннекатакомбной культуры было повреждено основное погребение. Судя по отчету, камера основного погребения не была повреждена. Однако останки и погребальный инвентарь, содержащийся в этой камере, были полностью разрушены, находились в виде отдельных костей и фрагментированных предметов. Второй особенностью использования памятника другой культуры является обряд создания большой по объему досыпки после создания впускного погребения. Курган, созданный таким методом, являлся одним из самых больших в группе, намного превышающим остальные насыпи в размерах.

Катакомбные курганы встраивались в образовавшуюся цепочку, и основная их часть своими размерами практически не отличалась от существующих памятников. На общем фоне выделялись курган 21, третья насыпь кургана 8, вторая и третья насыпи кургана 2 (диаметр от 40 до 70 м, высота от 3,5 до 6,5 м). Большое количество курганов и погребений восточноманычской катакомбной культуры позволило выявить гораздо больше информации об особенностях межкультурного взаимодействия.

Впускные погребения восточноманычской катакомбной культуры практически никогда не нарушали основные погребения ни в «своих», ни в «чужих» курганах. Выявлен лишь один случай, когда впускное катакомбное незначительно повредило основное погребение другой культуры. Еще в одном случае впускное детское катакомбное погребение было сооружено во входной 
шахте однокультурного женского погребения, что может рассматриваться как преднамеренное действие, целью которого было создание своеобразного семейного склепа.

Инокультурные насыпи активно использовались для создания впускных погребений, причем их количество в одном кургане не зависело от размера его насыпи. Число материковых погребений ни в одном случае не превышало двух, следов досыпок не выявлено. В собственно катакомбных курганах количественные показатели несколько иные - в малых по размеру курганах не выявлено материковых погребений, количество впускных погребений минимально, досыпок не прослежено. Судя по анализу месторасположения и количества впускных погребений в курганах среднего размера, эти памятники изначально предполагали создание впускных материковых погребений. Однако по достижении их количества до двух-трех погребений в одном кургане, его насыпь подвергалась досыпке. Этот сложный обряд трудно истолковать однозначно, потому что он состоял из нескольких взаимосвязанных элементов. Безусловно, люди, останки которых обнаружены в основных погребениях, являлись носителями высокого социального статуса. Судя по всему, захороненные во впускных материковых погребениях тоже были представителями верхушки общества, но по каким-то причинам не были удостоены отдельного кургана. Возможно, для них было важнее находиться под одной насыпью с основным погребенным, а досыпка являлась символом создания нового кургана.

Из результатов проведенного анализа следует, что при изучении погребальных памятников раннего и среднего бронзового века важно обращать внимание не только на количественные показатели погребений в отдельных курганах. При подсчете количества впускных погребений обязательно необходимо учитывать культурно-хронологическую принадлежность основного погребения. Кроме того, важно знать такие дополнительные данные, как местоположение погребения в насыпи или под ней, имелись ли следы досыпок и так далее. Эти данные позволяют выявить дополнительные группы впускных погребений - от «рядовых» погребений в насыпи до «престижных» за- хоронений, после создания которых насыпь значительно увеличивали, и порой объем таких досыпок в несколько раз превосходил объем изначальной насыпи.

Характер использования межкурганного и подкурганного пространства представителями разных культур показал их толерантное отношение к инокультурным памятникам. Линейная структура курганной группы, протянувшейся по линии водораздела, говорит нам о единых принципах, которыми руководствовались строители при выборе места для нового кургана.

Интересным является процесс создания особенно крупных курганов (2 и 8), первые насыпи которых относились к степной северокавказской культуре, затем над ними было создано по две значительных насыпи, сделавших эти курганы самыми большими группами. Судя по тому, что изначально эти курганы были одними из самых больших в группе, в докатакомбное время именно размер этих памятников послужил одной из причин выбора именно их для создания последующих досыпок.

В результате изучения использования подкурганного пространства различных культур в одно- и поликультурных памятниках вывод является аналогичным: впускные погребения крайне редко нарушали основные и более ранние впускные погребения. Для восточноманычской катакомбной культуры удалось выявить различия в обряде совершения впускных погребений в «своих» и «чужих» курганах. Однако полученные результаты требуют проверки на материале изучения других погребальных памятников.

Проведенное исследование показало, что процесс смены культур раннего и среднего бронзового века на Ергенинской возвышенности происходил поэтапно, погребальные традиции постепенно сменяли одна другую, и эти процессы нашли свое отражение в особенностях устройства погребальных памятников. Изучение многочисленных материалов об археологических памятниках волго-манычских степей и сопредельных территорий с применением новых подходов и методик позволит осветить эти проблемы и ответить на многие вопросы межкультурного взаимодействия в бронзовом веке. 
Oriental Studies. 2020. Vol. 13. Is. 3

Таблица 1. Курганные могильники, исследованные в южной части Ергенинской возвышенности

[Table 1. Mound burial sites investigated in the south of the Ergeni Uplands]

\begin{tabular}{|c|c|c|c|}
\hline № & Могильник & $\begin{array}{c}\text { Кол-во курганов (в скобках } \\
\text { кол-во курганов энеолита и } \\
\text { бронзового века) }\end{array}$ & $\begin{array}{c}\text { Кол-во погребений (в скобках } \\
\text { кол-во погребений энеолита и } \\
\text { бронзового века) }\end{array}$ \\
\hline 1. & Элистинский (Элиста-3) & $37(23)$ & $123(92)$ \\
\hline 2. & Три Брата-1 & $28(17)$ & $112(74)$ \\
\hline 3. & Apxapa & $38(23)$ & $95(67)$ \\
\hline 4. & Кермен Толга & $44(22)$ & $84(55)$ \\
\hline 5. & Лола-1 & $24(22)$ & $71(62)$ \\
\hline 6. & Лола-2 & $17(10)$ & $42(31)$ \\
\hline 7. & Три Брата-2 & $31(3)$ & $35(3)$ \\
\hline 8. & Элиста-2 & $12(\min 1)$ & $34(18)$ \\
\hline 9. & Хар Зуха & $9(7)$ & $33(16)$ \\
\hline 10. & Бичкин Булук & $19(\min 1)$ & $28(12)$ \\
\hline 11. & Хар Зуха-2 & $3(3)$ & $17(13)$ \\
\hline 12. & Цаган Эльсин & $11(\min 1)$ & $16(8)$ \\
\hline 13. & Гашунский & $8(4)$ & $10(5)$ \\
\hline 14. & Промзона & $3(0)$ & $3(0)$ \\
\hline 15. & Чееря Хурул & $1(1)$ & $1(1)$ \\
\hline 16. & Элиста-1 & $1(1)$ & $1(1)$ \\
\hline & Итого: & $286(\min 139)$ & $705(461)$ \\
\hline
\end{tabular}

Таблица 2. Элистинский могильник. Культурно-хронологическая принадлежность основных и впускных погребений, с учетом совершенных досыпок (РКК - ранняя катакомбная культура; СтСК - степная северокавказская культура; ВМКК - восточноманычская катакомбная культура)

[Table 2. Elista grave field. Cultural and chronological affiliation of main and inlet burials (Early Catacomb culture, North Caucasian steppe culture, East Manych Catacomb culture)]

\begin{tabular}{|c|c|c|c|c|c|}
\hline \multirow[b]{2}{*}{ Тип погребения } & \multicolumn{5}{|c|}{ Культурно-хронологическая принадлежность } \\
\hline & $\begin{array}{c}\text { Ямная } \\
\text { культура } \\
\text { (2 кургана) }\end{array}$ & $\begin{array}{c}\text { РКК } \\
\text { (4 кургана) }\end{array}$ & $\begin{array}{c}\text { СтСК } \\
\text { (6 курганов) }\end{array}$ & $\begin{array}{c}\text { Ямно-катакомбная } \\
\text { группа } \\
\text { (нет курганов) } \\
\end{array}$ & $\begin{array}{c}\text { ВМКК } \\
\text { (11 курганов) }\end{array}$ \\
\hline Основное & 2 & 4 & 6 & - & 11 \\
\hline $\begin{array}{c}\text { Впускное в «свой» } \\
\text { курган }\end{array}$ & - & 2 & 2 & - & 20 \\
\hline $\begin{array}{c}\text { Впускное в } \\
\text { «чужой» курган }\end{array}$ & - & - & 2 & 2 & 26 \\
\hline $\begin{array}{c}\text { Впускное в } \\
\text { «чужой» курган } \\
\text { с совершением } \\
\text { досыпки }\end{array}$ & - & - & - & 1 & 2 \\
\hline $\begin{array}{c}\text { Впускное в } \\
\text { «чужой» курган } \\
\text { с совершением } \\
\text { повторной досыпки }\end{array}$ & - & - & - & - & 1 \\
\hline $\begin{array}{c}\text { Впускное в } \\
\text { «чужой» курган, } \\
\text { после его досыпки }\end{array}$ & - & - & - & - & 11 \\
\hline
\end{tabular}




\begin{tabular}{|c|c|c|c|c|c|}
\hline $\begin{array}{c}\text { Итого: } \\
92 \text { погребения }\end{array}$ & 2 & 6 & 10 & 3 & 71 \\
\hline
\end{tabular}

\section{Литература}

Андреева 2014 - Андреева М. В. Восточноманычская катакомбная культура: анализ материалов погребальных памятников. М.: ТАУС, 2014. 272 c.

Буваев 2009 - Буваев Д. А. Современное состояние курганного могильника «Элистинский» // Вестник Калмыцкого института гуманитарных иссследований РАН. 2009. № 1. C. 3-11.

Державин 1984 - Державин В. Л. Погребения в каменных ящиках средней бронзы в степном Предкавказье // Краткие сообщения Института археологии (КСИА). 1984. Вып. 177. C. 90-95.

Державин 1991 - Державин В. Л. Степное Ставрополье в эпоху бронзы. М.: ИА АН СССР, 1991. $186 \mathrm{c}$.

Карандеева 1957 - Карандеева М. В. Геоморфология Европейской части СССР [электронный ресурс] // Уч. пособ. М.: МГУ, 1957. 314 c. URL: http://stepnoy-sledopyt.narod.ru/ geologia/karandeeva/2/2.htm (дата обращения: 03.03.2020).

Кекеев 2018 - Кекеев Э. А. Жертвенные комплексы эпохи бронзы из насыпей курганов (по материалам курганных групп «Восточный Маныч») // Бюллетень Калмыцкого научного центра РАН. 2018. № 4 (8). C. 26-45. DOI: $10.22162 / 2587-6503-2018-4-8-26-45$

Кекеев 2019 - Кекеев Э. А. Жертвенные комплексы в курганах бронзового века (по материалам могильников Ергенинской возвышенности) // Oriental Studies. 2019. № 4. C. 580-600. DOI: 10.22162/2619-0990-201944-4-580-600

Кияшко 2002 - Кияшко A. В. Культурогенез на востоке катакомбного мира. Волгоград, 2002. $268 \mathrm{c}$.

Мимоход 2013 - Мимоход P. А. Лолинская культура. Северо-западный Прикаспий

\section{References}

Andreeva M. V. East Manych Catacomb Culture: Analyzing Materials from Burial Monuments. Moscow: TAUS, 2014. 272 p. (In Russ.)

Buvaev D. A. Elista burial mound group: contemporary conditions revisited. Bulletin of the Kalmyk Institute for Humanities of the RAS. 2009. No. 1. Pp. 3-11. (In Russ.)

Derzhavin V. L. Bronze Age in Stavropol Steppe. Moscow: Institute of Archaeology (USSR на рубеже среднего и поздне-го периодов бронзового века: мат-лы охранных археологических исследований. Т. 16. М.: ИА РАН, 2013. 568 c.

Очир-Горяева 2008 - Очир-Горяева М. A. Археологические памятники волго-манычских степей: (свод памятников, исследованных на территории Республики Калмыкия в 1929-1997 гг.). Элиста: Герел, 2008. 298 c.

Очир-Горяева 2017 - Очир-Горяева М. А. Древние некрополи Ергенинской возвышенности. Элиста: КалмНЦ РАН, 2017. 420 с.

Синицын, Эрдниев 1971 - Синицьын И. В., Эрдниев У. Э. Элистинский курганный могильник. Элиста: Калм. кн. изд-во, 1971. 139 с.

Синицын 1978 - Синицьын И. В. Древние памятники Восточного Маныча. В 2 ч. Саратов: изд-во Саратов. гос. ун-та, 1978. Ч. 1. 130 с.; Ч. 2.117 c.

Спиридонов 1978 - Спиридонов А. И. Геоморфология европейской части СССР. Уч. пособ. М.: Высшая школа, 1978. 332 с.

Шишлина 2007 - Шишлина Н. И. Северо-Западный Прикаспий в эпоху бронзы (VIII тыс. до н. э.). Труды Государственного Исторического музея. Вып. 165. М.: ГИМ, 2007. $400 \mathrm{c}$.

Эрдниев 1981 - Эрдниев У. Э. Древнейшая история заселения территории Калмыкии (материалы) // Археологические памятники эпохи бронзы и средневековья. Элиста: КНИИИФЭ, 1981. С. 3-24.

Эрдниев 1982a - Эрдниев У. Э. Археологические памятники Южных Ергеней. Элиста: Калм. кн. изд-во, 1982. 153 с.

Эрдниев 19826 - Эрдниев У. Э. Калмыцкая степь в скифо-сарматское время // Памятники Калмыкии каменного и бронзового веков. Элиста: КНИИИФЭ, 1982. С. 3-23.

Academy of Sciences), 1991. 186 p. (In Russ.) Derzhavin V. L. Middle Bronze Age in the Ciscaucasia: stone-box burials. Brief Communications of the Institute of Archaeology (KSIA). 1984. No. 177. Pp. 90-95. (In Russ.)

Erdniev U. E. Ancient population history of Kalmykia. In: Archaeological Monuments. Bronze and Middle Ages. Elista: Kalmyk Research Institute of History, Philology and Economics, 1981. Pp. 3-24. (In Russ.) 
Erdniev U. E. Archaeological Monuments of the Southern Ergeni. Elista: Kalmyk Book Publ., 1982. 153 p. (In Russ.)

Erdniev U. E. Kalmyk Steppe in the ScythoSarmatian era. In: Stone and Bronze Age Monuments of Kalmykia. Elista: Kalmyk Research Institute of History, Philology and Economics, 1982. Pp. 3-23. (In Russ.)

KarandeevaM. V.EuropeanUSSR: Geomorphology. Textbook. Moscow: Moscow State University, 1957. 314 p. Available at: http://stepnoysledopyt.narod.ru/geologia/karandeeva/2/2 htm. (accessed: March 3, 2020). (In Russ.)

Kekeev E. A. Sacrificial complexes in Bronze Age mounds: archaeological evidence from burials of the Ergeni Upland. Oriental Studies. 2019. No 4. Pp. 580-600. (In Russ.) DOI: 10.22162/2619-0990-2019-44-4-580-600

Kekeev E. A. Sacrificial complexes in Bronze Age tumuli: a case study of the East Manych kurgan groups. Bulletin of the Kalmyk Scientific Center of the RAS. 2018. No. 4 (8). Pp. 26-45. (In Russ.) DOI: 10.22162/2587-6503-2018-4-826-45

Kiyashko A. V. Culture Genesis in the East of the Catacomb World. Volgograd, 2002. 268 p. (In Russ.)
Mimokhod R. A. Lola Culture: Northwestern Caspian at the Turn of the Late Bronze Age. Ser.: Materials of Rescue Archaeological Investigations. Vol. 16. Moscow: Institute of Archaeology (RAS), 2013. 568 p. (In Russ.)

Ochir-Goryaeva M. A. Ancient Necropolises of the Ergeni Uplands. Elista: Kalmyk Scientific Center (RAS), 2017. 420 p. (In Russ.)

Ochir-Goryaeva M. A. Archaeological Monuments of the Volga-Manych Steppe: A Review of Kalmykia's Monuments Investigated in 19291997. Elista: Gerel, 2008. 298 p. (In Russ.)

Shishlina N. I. Bronze Age in the Northwestern Caspian: $5^{\text {th }}-3^{\text {rd }}$ Millennium BC. Ser.: Transactions of the State Historical Museum. Vol. 165. Moscow: State Historical Museum, 2007. 400 p. (In Russ.)

Sinitsyn I. V. Ancient Monuments of the East Manych. In 2 vols. Saratov: Saratov State University, 1978. Vol. 1, 130 p.; vol. 2, 117 p. (In Russ.)

Sinitsyn I. V., Erdniev U. E. Elista Burial Mound Site. Elista: Kalmyk Book Publ., 1971. 139 p. (In Russ.)

Spiridonov A. I. European USSR: Geomorphology. Textbook. Moscow: Vysshaya Shkola, 1978. 332 p. (In Russ.) 